\title{
NOVA GENERACIJA PODUZETNIKA; GENERACIJA Z
}

\author{
Vedrana Šimunić Rod, mag. oec. \\ Privatna gimnazija i ekonomska škola Katarina Zrinski \\ Selska cesta 119, 10110 Zagreb, Republika Hrvatska \\ Mobitel: 098180 4066, e-mail: vedrana.simunic.rod@gmail.com
}

\section{SAŽETAK}

Suvremeni način življenja, uvođenje tehnologije u sve sfere života, netolerantnost te želja za neovisnošću i uspjehom stvorili su novu generaciju poduzetnika, takozvanu Z generaciju. Generacija mladih ljudi koji dolaze na tržište rada s novim pogledom na svijet postaju sve zanimljiviji znanstvenicima, a njihova želja za ostvarenjem poduzetničkih ideja postaje glavna tema svih generacija ljudi. Z generacija, zbog svojih specifičnosti, moći stvaranja trenda te navika koje posjeduje postaje glavna tema ovog rada. Cilj rada je istražiti radi li se doista o novoj generaciji poduzetnika kroz karakteristike koje posjeduju pripadnici $Z$ generacije te koliko tehnologija utječe na kreiranje njihove svijesti tj. buduće poslovne ideje. U radu će se primarnim i sekundarnim istraživanjem detaljnije pojasniti cilj rada kao i postavljene hipoteze. Sekundarnim istraživanjem autorica će utvrditi dolazi li doista s godinama do povećanja broja poduzetnika u Republici Hrvatskoj koji su pokazatelj povezanosti tehnologije $i$ poduzetništva dok će fokus primarnog istraživanja biti na Z generaciji, njihovim navikama, idejama, prihvaćanju tehnologije kao suvremenom načinu življenja te na koji način mladi iskorištavaju tehnologiju i usmjeravaju je prema ostvarenju svojeg cilja. Na samom kraju rada utvrdit će se koliko su mladi stvarno zainteresirani za poduzetništvo i samozapošljavanje te ima li utjecaj rano poimanje poduzetništva na ostvarenje vlastitog poduzetničkog pothvata.

Ključne riječi: Z generacija; tehnologija; poduzetništvo; samozapošljavanje 


\section{UVOD}

Užurbani i suvremeni način života, netolerantnost te želja za neovisnošću i uspjehom stvorili su novu generaciju poduzetnika, takozvanu generaciju Z. Generacija mladih ljudi koji dolaze na tržište rada s novim pogledom na svijet uz svakodnevno korištenje tehnologije postaju sve zanimljiviji znanstvenicima, a njihova želja za ostvarenjem poduzetničkih ideja postaje glavna tema svih generacija. Generacija Z, zbog specifičnosti vremena u kojem se nalaze, karakteristikama koje posjeduju te moći stvaranja trenda, postaju glavna tema ovog rada tj. predmet istraživanja. Na samom početku rada autorica će se osvrnuti i pojasniti pojmove poduzetništva i poduzetnika radi jednostavnijeg shvaćanja ciljeva rada te objasniti karakteristike generacija ljudi s osvrtom na generaciju Z. Stoga, ciljevi istraživanja su sljedeći:

- definirati pojmove poduzetništva, poduzetnika te generacija s fokusom na generaciju Z

- dobiti uvid u trenutno stanje poduzetnika u Republici Hrvatskoj

- $\quad$ uočiti postoje li trendovi rasta ili pada poduzetnika u Republici Hrvatskoj

- detektirati probleme istraživanja i najveća ograničenja rada

- $\quad$ prikazati rezultate istraživanja dobivenih anketnim upitnikom

- objektivno interpretirati rezultate dobivene anketnim upitnikom i pojasniti hoće li se nadolazeća generacija, generacija $Z$, pokazati kao generacija novih inovativnih i specifičnih poduzetnika.

Metode istraživanja koje je autorica koristila u ovome radu istraživanje su za stolom, metoda analize te primarna kvantitativna metoda, tj. korištenje anketnog upitnika distribuiranog većem broju pripadnika generacije $Z$ te manjem broju pripadnika X, Y i Babyboom generacije u Republici Hrvatskoj temeljenog na slučajnom odabiru. Doprinos rada ogleda se u činjenici kako je poduzetništvo i inovativnost (ne samo tehnološka, već i idejna) ključan element koji pokreće gospodarstvo. Kada bi se utvrdila povezanost generacije $Z$ s visokim stupnjem kreativnosti i inovativnosti zbog ranog učenja poduzetništva u osnovnim i srednjim školama te korištenja tehnologije u svrhu kreiranja inovativnog proizvoda, mogao bi se uložiti potreban napor u stvaranje i realizaciju inovativne ideje kod pripadnika generacije $Z$, generacije mladih poduzetnika, a sve u svrhu osnaživanja gospodarstva u cjelini.

\section{POJMOVNO ODREĐENJE PODUZETNIŠTVA I PODUZETNIKA}

Mnogi autori smatraju kako u suvremenom poslovnom svijetu nema pokretanja proizvodnje niti poslovnih aktivnosti bez poduzetništva. Glavni cilj poduzetništva je stvoriti nove vrijednosti pokretanjem i razvojem novih poduzeća, zapošljavanjem, razvojem inovacija, ulaganjem i širenjem na nova tržišta, stvaranjem novih proizvoda, novih tehnologija i tehnoloških rješenja (Kolaković, 2006, str. 1). Zbog različitog poimanja poduzetništva, poprilično je teško navesti samo jednu definiciju poduzetništva. Stoga se može reći kako je poduzetništvo proces stvaranja nečeg novog ulaganjem neophodnog vremena i napora te pratećih financijskih, fizičkih i društvenih rizika uz prihvaćanje odgovarajućih nagrada u novčanom i osobnom zadovoljstvu i neovisnosti (Hirsch, Peters i Shepherd, 2005, str. 
8). Prema Vukoviću, poduzetništvo je ljudska kreativna i inovativna djelatnost preko koje se kombiniraju različiti tipovi resursa kako bi se proizveli potrebni proizvodi i usluge radi zadovoljenja ljudskih potreba (Vuković, 1999, str. 33) dok Škorić objašnjava poduzetništvo kao ulaganje radi ostvarivanja dobiti ili profita (Škorić, 1995, str. 23). U svim navedenim definicijama mogu se selektirati zajednički elementi, a to su kreativnost i inovacije, resursi i osnivanje organizacija te stjecanje profita i rasta pod rizikom i nesigurnošću. Upravo navedeni zajednički elementi predstavljaju glavne karakteristike uspješnog poduzetnika.

Zimmerer i Scarborough poduzetnika definiraju kao osobu koja pokreće nove poslove, samostalno organizira i kontrolira tijek poslovanja te stvara nove poslovne mogućnosti usprkos riziku i neizvjesnosti, a sve u svrhu stjecanja profita i rasta (Zimmerer i Scarborough, 2005, str. 3). S druge strane Hirsch, Peters i Sheperd smatraju kako je poduzetnik inovator, tj. pojedinac koji razvija nešto jedinstveno te na revolucionaran način, primjenom inovacija, proizvodi proizvod (Hirsch, Peters i Shepherd, 2005, str. 7). Dok Gorupić i Gorupić definiraju poduzetnika kao poslovno kreativnu, inovativnu i dinamičnu osobu, sposobnu za brzim uočavanjem pojava i problema te spremnu na rizik i maksimalne napore. Poduzetnik je sposoban pronalaziti uspješne poslovne ideje, poslovne akcije, mjesto na tržištu i tehnologiju te ih brzo i na vrijeme uspješno realizirati (Gorupić i Gorupić, 1990, str. 12). Drugim riječima, poduzetnici djeluju na ono što smatraju da je prikladno jer postoji veliki broj mogućnosti koje za sobom istiskuju i veliku nesigurnost pa moraju koristiti svoju prosudbu o tome hoće li djelovati ili ne (Hirsch, Peters i Shepherd, 2016, str. 6). Što znači da poduzetnici moraju biti i jesu najbolja kombinacija talenta, znanja i sposobnosti s ulaganjem odgovarajućeg kapitala koje za sobom nosi neizvjesnost i rizik, ali i unošenje inovacija u poduzeće (Bahtijarević-Šiber i Sikavica, 2001, str. 409).

Kako su inovacije i poduzetništvo usko povezani te su temelj razvoja napredne ekonomije i društva u cjelini, a sve u svrhu razvoja suvremenog okruženja u kojem obiluje konkurencija (Gregorić, Hegeduš i Kolenko, 2018, str. 25) potrebno je detaljno razmotriti buduće poduzetnike koji tek dolaze na tržište rada. Ti poduzetnici odrasli su uz mobitele i suvremenu tehnologiju te kao takvi posjeduju novu dimenziju inovativnosti koja će biti predmetom ovoga rada, ne samo u tehnološkom smislu, već i u smislu kreiranja nove ideje proizvoda.

\section{PRIPADNICI RAZLIČITIH GENERACIJA}

Generacija je grupa ljudi određena godinama tj. osobe koje su rođene tijekom određenog razdoblja, a koje su odrastale na sličan način i imale slična iskustva te su stoga njihove vrijednosti i stavovi slični (Rimac, 2012, str. 3, prema Notter, 2002). Mnogi autori koji su pisali o različitim generacijama ne mogu se složiti gdje točno neka generacija počinje i završava, što se vidi na slici 1., ali ono u čemu se svi slažu jest činjenica kako postoje sljedeće grupe: Veterani, Baby-boom generacija, generacija $\mathrm{X}$, generacija $\mathrm{Y}$, generacija $\mathrm{Z}$ i najnovija generacija Alfa. 
Slika 1 Grafički prikaz godina rođenja pripadnika generacija

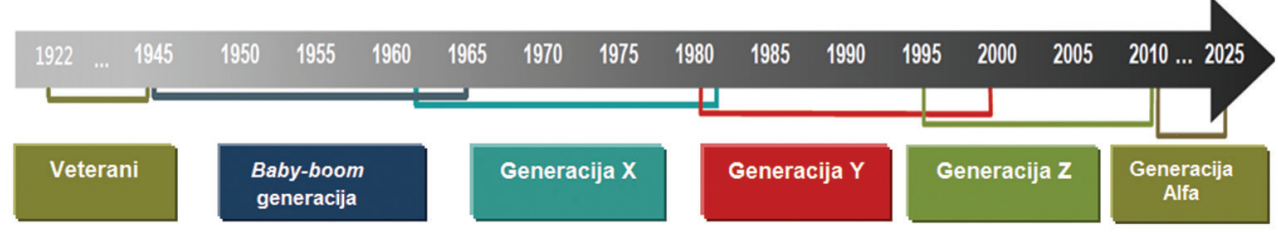

Izvor: Rimac, 2012., prema Grail Research Analysis, 2011.

Zemke, Raines i Filipczak (2000) objašnjavaju kako ne postoje stroge granice gdje jedna generacija prestaje, a druga počinje, ali u svojem radu ipak navode sljedeća razdoblja koja obilježavaju pojedine generacije:

- Veterani - rođeni u razdoblju od 1922. do 1943. godine. Generacija koja je rođena uglavnom prije Drugog svjetskog rata i prve uspomene povezane su im s ratom.

- Baby-boom generacija - rođena između 1943. i 1960. godine. Rođeni su nakon Drugog svjetskog rata i odrasli su u razdoblju izrazitog optimizma, velikih prilika i napretka.

- Generacija X - rođena u razdoblju od 1960. do 1980. godine. Rođeni su nakon bljeska Baby-boom generacije i u njihovoj su sjeni te su rođeni za vrijeme napretka Azijskih tigrova Hong Konga, Južne Koreje, Singapura i Tajvana.

- Generacija Y - rođena između 1980. i 2000. godine. Roditelji su im pripadnici Babyboom generacije ili rani pripadnici Generacije X. Odrasli su u visokotehnološkom i optimističnom vremenu.

Navedeni autori u svojem djelu ne navode ostale generacije, već se u novijim djelima (Han, 2007; Knežević 2010; Levickaitè, 2010) govori o novoj generaciji koja je nastala ulaskom u novo tisućljeće zvanom generacijom Z. Generacija Z rođena je sredinom devedesetih godina i odrasla je s novom tehnologijom (Levickaitè, 2010). Uz generaciju Z navodi se i najnovija generacija Alfa koja nije relevantna za ovaj rad budući da su pripadnici navedene generacije izuzetni mladi i nisu u stadiju razmišljanja o poduzetništvu i osnivanju vlastitog posla te razumijevanju istih pojmova. S obzirom na to da svaka generacija ima svoja specifična obilježja, za shvaćanje generacije $Z$ u istraživačkom dijelu rada, potrebno je ukratko pojasniti svaku od navedenih generacija.

\subsection{Generacija veterani (1922. - 1943.)}

Često nazivani „Tradicionalisti“, generacija veterana živjela je za vrijeme Velike depresije, Drugog svjetskog rata i Korejskog rata. U SAD-u 50\% pripadnika navedene generacije ratni su veterani i ujedno patrioti (McNamara, 2005). Prema Zemke, Raines i Filipczak (2000) veterani su osobe koje vjeruju u logiku, a ne u magiju (engl. believe in logic, not magic) te su izrazito disciplinirani i konzervativni. 


\subsection{Baby-boom generacija (1943. - 1960.)}

Generacija koja je odrasla u optimističnom i pozitivnom vremenu jer su njihovi roditelji zbog gospodarskog napretka mogli osigurati sve ono što sami nisu mogli imati (Kindrick Patterson, 2007, str. 18). Stopa nataliteta bila je izrazito velika. Bili su izričito idealistični i optimistični, razmišljali su svojom glavom, preispitivali autoritet i živjeli su punim plućima (McNamara, 2005). Ova generacija često je nazivana i „ja“ generacija jer su sebe doživljavali kao zvijezde i nisu se brinuli za budućnost (Zemke, Raines i Filipczak, 2000).

\subsection{Generacija X (1960. - 1980.)}

Često se naziva „izgubljenom“ generacijom jer su pripadnici navedene generacije odrasli u sjeni Baby-boomersa (Zemke, Raines i Filipczak, 2000, str. 93). S obzirom na to da su se prilikom djetinjstva osjećali zapostavljenima jer su njihovi roditelji mnogo radili, oni se usmjeravaju na obitelj i kvalitetu života radije nego na karijeru (Kindrick Patterson, 2007, str. 19). Važnija im je ravnoteža između poslovnog i obiteljskog života pa se za ovu generaciju može reći da „radi kako bi živjela“ za razliku od Baby-boom generacije koja „živi da bi radila" (Zemke, Raines i Filipczak, 2000). Ono što je bitno navesti jest kako je Generacija $X$ tehnološki osviještena (Zemke, Raines i Filipczak, 2000) jer su vidjeli začetke osobnih računala te razvoj Interneta kao alata za poslovne svrhe (Levickaitè, 2010).

\subsection{Generacija Y (1980. - 2000.)}

Internet generacija, Milenijanci ili generacija Y (Zemke, Raines i Filipczak, 2000) generacija je koju obilježava mir i prosperitet. Pripadnici ove generacije su urbani, fokusirani, nestrpljivi i idealistični, ali ih je iskustvo ipak naučilo da s oprezom gledaju na budućnost (Montana i Petit, 2008, str. 139). Poznati su i kao „digitalna generacija“ jer nisu iskusili svijet bez tehnologije (Kindrick Patterson, 2007, str. 20). Na ovu generaciju značajan utjecaj imao je razvoj novih medija i mogućnost trenutačne komunikacije putem društvenih mreža (Levickaitė, 2010). Pristup računalima ova generacija imala je još u osnovnoj školi i vrlo rano su dobili pristup Internetu (Glass, 2007).

\subsection{Generacija Z (1995. - 2010.)}

Meister i Willyerd (2010) generaciju Z još nazivaju i „Generacija 2020.“ jer će velika većina visokoobrazovanih pripadnika ove generacije ući na tržište rada. Pripadnici navedene generacije rođeni su u hiper-umreženom svijetu (engl. hiper-networked world), a mnogi od njih su se prije početka osnovne škole susreli s društvenim mrežama (Meister i Willyerd, 2010). Predviđa se kako će ova generacija biti više ekološki osviještena od prethodnih generacija i smatra se kako će navedenu generaciju obilježiti visok stupanj nepovjerenja prema korporacijama zbog čega će biti više skloni mijenjaju posla i/ili karijere (Han, 2007) ili osnivanju vlastitog. Institucija Mission and Ministry (2010. prema Levickaitè, 2010.) naglašava da ova generacija odrasta brže te počinje učiti ranije. Ista organizacija navodi da je generacija Z internetski i tehnološki osviještena generacija, a njeni pripadnici se razvijaju u osobe koje mogu raditi više zadataka odjednom (engl. multi-tasking). 
Prensky (2001) je generaciju Z nazvao „urođeni digitalci“ (engl. Digital Native) jer smatra da su pripadnici navedene generacije sposobni primati informacije izrazito brzo i paralelno s drugim zadacima te je naglasio da prednost daju grafici umjesto teksta i zahtijevaju olakšan pristup svim informacijama. Također je zanimljivo navesti kako pripadnici ove generacije primaju i obrađuju dobivene informacije jako brzo, ali zahtijevaju olakšan pristup istima. Drugim riječima, sposobnosti i mogućnosti koje posjeduje generacija Z daje naslutiti, prema predviđanjima ekonomista, da će ova generacija pokositi tržište rada u najboljem mogućem smislu te da se radi o budućim znanstvenicima, istraživačima i stručnjacima koji će uz pomoć tehnologije svijet oblikovati onako kako žele (Reić, 2015).

\section{PODUZETNIŠTVO U REPUBLICI HRVATSKOJ}

Glavni pokretač razvoja svih suvremenih gospodarstava je poduzetništvo. Republika Hrvatska nije iznimka jer je poduzetništvo u Republici Hrvatskoj najperspektivniji dio gospodarstva (Gradečak, 2016, str. 12). Najrazvijenije zemlje svijeta uključujući i zemlje Europske unije, prepoznale su važnost podržavanja poduzetništva, stalnu potrebu za stvaranjem poduzetničkog ozračja te poticanje poduzetničkog obrazovanja u nacionalnom kontekstu (Gradečak, 2016, str. 43). Kako bi se vidio stvarni pokazatelj utjecaja poduzetništva na gospodarstvo te utječe li obrazovanje o poduzetništvu na broj osoba koje postaju poduzetnikom, autorica će pokušati objasniti temeljem dolje prikazane tablice broja poduzetnika u Republici Hrvatskoj kroz promatrano razdoblje.

Tablica 1 Broj poduzetnika u Republici Hrvatskoj

\begin{tabular}{|l|c|}
\hline Promatrane godine & Broj poduzetnika u Republici Hrvatskoj \\
\hline $\mathbf{2 0 0 7 .}$ & 83532 \\
\hline $\mathbf{2 0 0 8 .}$ & 89656 \\
\hline $\mathbf{2 0 0 9 .}$ & 91320 \\
\hline $\mathbf{2 0 1 0 .}$ & 96758 \\
\hline $\mathbf{2 0 1 1 .}$ & 98530 \\
\hline $\mathbf{2 0 1 2 .}$ & 97254 \\
\hline $\mathbf{2 0 1 3 .}$ & 101191 \\
\hline $\mathbf{2 0 1 4 .}$ & 104470 \\
\hline $\mathbf{2 0 1 5 .}$ & 106569 \\
\hline $\mathbf{2 0 1 6 .}$ & 114483 \\
\hline $\mathbf{2 0 1 7 .}$ & 120081 \\
\hline $\mathbf{2 0 1 8 .}$ & 131117 \\
\hline
\end{tabular}

Izvor: Financijska agencija, Registar godišnjih financijskih izvještaja, https://www.fina.hr/

Tablica prikazuje broj poduzetnika u Republici Hrvatskoj kroz promatrano razdoblje od 2007. godine do 2018. godine. Promatrano razdoblje obuhvaća tri različita i vrlo ključna perioda u gospodarstvu Republike Hrvatske, pred krizno razdoblje, financijsku i gospodarsku krizu te oporavak. Prema podatcima Financijske agencije broj poduzetnika u Republici 
Hrvatskoj konstantno raste izuzev 2012. godine kada je zabilježen pad broja poduzetnika. Odnosno, jasno je vidljiv trend rasta poduzetnika. Iz tablice se primjećuje kako se, neovisno o financijskoj i gospodarskoj situaciji Republike Hrvatske, broj poduzetnika povećava. Razlog tome može se pronaći u želji pojedinca za samostalnošću i neovisnošću, ali i kontinuiranim edukacijama poduzetnika te sve većoj popularnosti pojma poduzetništva i poduzetnika.

Kako bi se i dalje nastavio trend rasta broja poduzetnika, Republika Hrvatska bi trebala biti usmjerena na prihvaćanje poduzetništva kao društvene, nacionalne, gospodarske i odgojno-obrazovne vrijednosti. Vrijednosna usmjerenost predstavlja stvaranje mogućnosti za razvijanje poduzetničkih kompetencija počevši od najniže do najviše razine obrazovanja, osposobljavanje i obrazovanje za poduzetništvo kroz formalno, neformalno i informalno obrazovanje i učenje te poticanje poduzetništva kao gospodarskog zahtjeva (Gradečak, 2016, str. 43). Također je bitno napomenuti kako poduzetništvo ima znanstveno priznanje kroz istraživačke konferencije o poduzetništvu, znanstvenim časopisima o poduzetništvu, katedrama na visokim učilištima čime se vidi da je postignuta legitimnost poduzetništva kao obrazovnog područja. Vlada od poduzetničkog obrazovanja očekuje utjecaj na poboljšanje gospodarske situacije u društvu stvaranjem novih inovativnih poslova, jačanje inovativnosti za gospodarski razvoj zemlje, poticanje inovativnog poduzetničkog ponašanja pojedinca u društvu, podučavanje za poduzetništvo i podučavanje o poduzetništvu. Jer je najvažnija uloga poduzetničkog obrazovanja razviti poduzetnička znanja i vještine, ponašanja i osobine koji će osigurati snalaženje u novim uvjetima, složenim situacijama i pritiscima globalizacije na društvo, organizaciju i pojedince (Hunjet i Kozina, 2014). A ono najvažnije za Republiku Hrvatsku jest činjenica kako rast poduzetništva vodi ka smanjenju udjela nezaposlenosti, a poduzetništvo daje pozitivan doprinos gospodarskom rastu.

\section{EMPIRIJSKO ISTRAŽIVANJE OBILJEŽJA GENERACIJE Z}

Istraživanje se bavi obilježjima generacije $Z$ te proučava povezanost između visokog stupnja kreativnosti i inovativnosti zbog ranog učenja poduzetništva u školama te korištenja tehnologije, a sve u svrhu kreiranja inovativnog proizvoda. Uz gore navedene ciljeve rada, glavni je cilj utvrditi postaje li generacija Z nova generacija poduzetnika. Kako bi se navedeni cilj potvrdio ili negirao, autorica je izradila anketni upitnik koji se sastoji od 16 pitanja raspoređena u 3 cjeline: (1) osobne karakteristike ispitanika, (2) karakteristike generacije Z i (3) karakteristike generacije Z s osvrtom na poduzetništvo. Prva cjelina se sastoji od 3 pitanja, druga cjelina se sastoji od 12 pitanja dok treća cjelina sadržava pitanja kreirana unutar tablice. Sva pitanja treće cjeline strukturirana su na način da ispitanik zaokružuje odgovor od jedan do pet, ovisno o navedenoj tvrdnji i stupnju slaganja s njom. Zaokruživanjem broja jedan u određenoj tvrdnji označava kako se ispitanik izrazito ne slaže s navedenom tvrdnjom, a broj pet označava potpuno slaganje s navedenom tvrdnjom.

Svrha analize jest utvrditi dolazi li na tržište rada nova generacija poduzetnika koja će više ili manje svojim radom, aktivnošću i inovativnošću utjecati na razvoj gospodarstva u cjelini te koje promijene nas mogu očekivati njihovim djelovanjem. Nadalje, istraživanjem se želi dobiti odgovor na četiri postavljene hipoteze, a to su: $\mathrm{H}_{1}$ - Generacija $\mathrm{Z}$ je generacija „urođenih digitalaca“, $\mathrm{H}_{2}$ - generacija $\mathrm{Z}$ je ekološki osvještenija naspram drugih generacija, 
$\mathrm{H}_{3}$ - pripadnici generacije $\mathrm{Z}$ žele osnovati vlastita poduzeća i $\mathrm{H}_{4}$ - dualno obrazovanje ima za cilj ojačati poduzetništvo u Republici Hrvatskoj. Osnovna pretpostavka koja je ujedno i razlog pisanja i istraživanja rada glasi: Generacija Z je nova generacija poduzetnika koja svojim digitalnim iskustvom i suvremenim promišljanjem na poduzetništvo kreira smjer moderne ekonomije i pozitivno utječe na gospodarski rast u cjelini.

$U$ istraživanju su sudjelovali pripadnici Baby-boom generacije, generacije $X$, generacije $Y$ i generacije Z. Ukupno je anketirano 177 osoba i to 6 osoba pripadnika Baby-boom generacije, 14 osoba pripadnika generacije X, 20 osoba pripadnika generacije Y i 137 osoba generacije $\mathbf{Z}$ kao glavne promatrane generacije. Tablica 2 i graf 1 prikazuju broj ispitanika prema generacijama.

Tablica 2 Ispitanici po generacijama

\begin{tabular}{|l|c|c|}
\hline & muško & žensko \\
\hline $\begin{array}{l}\text { Baby-boom generacija } \\
(1943 .-1960 .)\end{array}$ & 4 & 2 \\
\hline $\begin{array}{l}\text { Generacija X } \\
(1960 .-1980 .)\end{array}$ & 4 & 10 \\
\hline $\begin{array}{l}\text { Generacija Y } \\
\text { (1980.-2000.) }\end{array}$ & 6 & 14 \\
\hline $\begin{array}{l}\text { Generacija Z } \\
\text { (1995.-2010.) }\end{array}$ & 97 & 40 \\
\hline UKUPNO & 111 & 66 \\
\hline
\end{tabular}

Izvor: anketni upitnik

Najveći broj ispitanika je generacije $Z$ s obzirom na to da je promatrana generacija i samim time relevantna za ovaj rad, dok rezultati ispitanika drugih generacija služe za usporedbu i potvrdu ili negiranje postavljenih hipoteza.

\section{Graf 1 Ispitanici po generacijama}

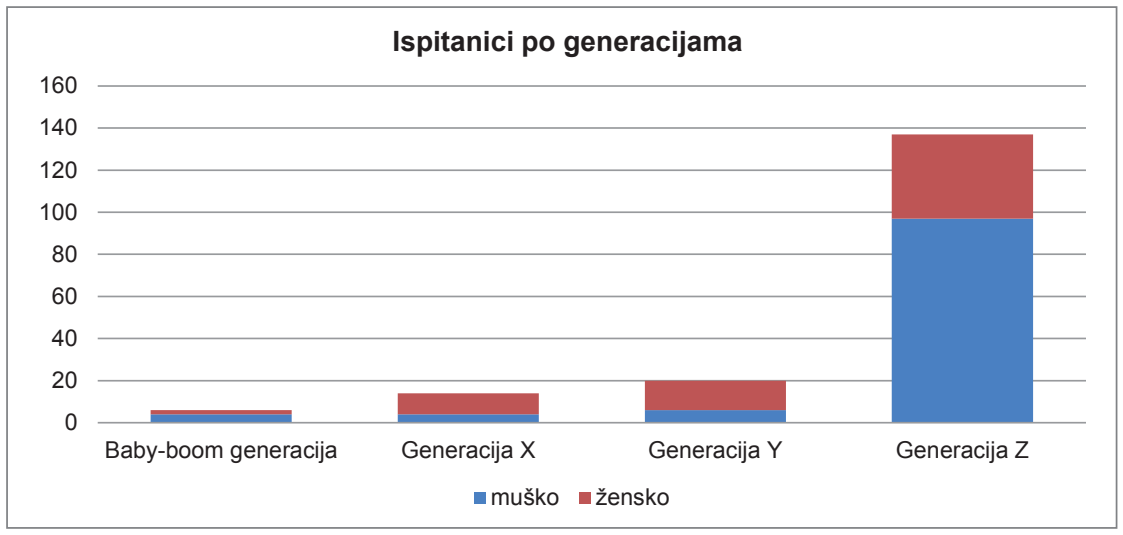

Izvor: anketni upitnik 
Iz grafa se jasno vidi zastupljenost broja ispitanika generacije Z, ali i odnos muškaraca i žena koji su sudjelovali u istraživanju. Svi ispitanici izabrani su slučajnim odabirom. Osnovni kriterij za odabir ispitanika bila je dobna granica odnosno pripadnost generaciji. Uz dobnu granicu ispitanici su se trebali izjasniti i o području stanovanja. Graf 2 prikazuje rezultate ispitanika.

\section{Graf 2 Područje stanovanja ispitanika po generacijama}

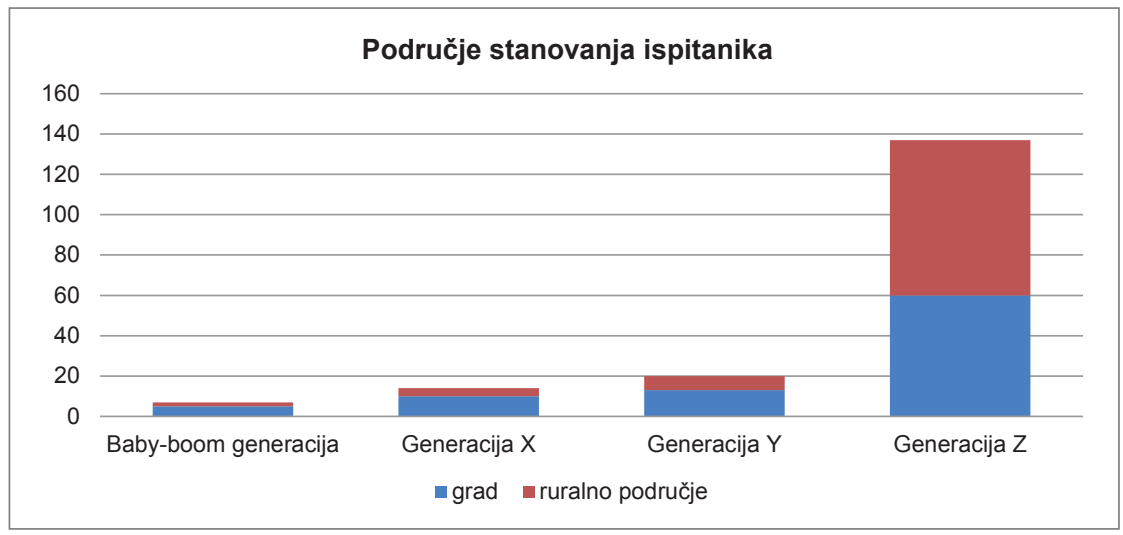

Izvor. Anketni upitnik

Iz grafa se može primijetiti kako je u svim generacijama podjednak broj ispitanika koji dolaze iz grada i iz ruralnog područja. Samim time pokazuje se raspon raznolikosti ispitanika i njihovih razmišljanja kako bi rezultati anketnog upitnika bili što vjerodostojniji. S obzirom na to da je ograničenje rada sam broj ispitanika, ovim načinom zastupljeni su svi segmenti koji mogu ulaziti u konačni rezultat rada. Uz navedeno, bitno je naglasiti kako su ispitanici bili učenici osnovnih škola, srednjih strukovnih škola zanimanja ekonomist iz grada Zagreba te ruralnih područja kao i učenici gimnazijskog usmjerenja u istoj kombinaciji. Nadalje, ispitanici su bili učenici trogodišnjih i četverogodišnjih strukovnih zanimanja iz grada Zagreba te ruralnih područja te studenti ekonomije. Pripadnici ostalih generacija su visokoobrazovane osobe kao i osobe sa završenom srednjom stručnom spremom iz cijele Republike Hrvatske.

\subsection{Rezultati istraživanja i diskusija rezultata istraživanja}

Kako bi se utvrdilo u kojoj mjeri i na koji način pripadnici različitih generacija se služe Internetom, postavljeno je nekoliko pitanja. Dolje navedena pitanja odgovorit će na prvu postavljenu hipotezu koja glasi: $\mathrm{H}_{1}$ - generacija $\mathrm{Z}$ je generacija „urođenih digitalaca“. 
Tablica 3 Koliko si imao godina kada si dobio svoj prvi mobitel?

\begin{tabular}{|l|c|c|c|c|}
\hline Godine & Baby-boom generacija & Generacija X & Generacija Y & Generacija Z \\
\hline $\mathbf{7 - 1 0}$ godina & - & - & $15 \%$ & $62 \%$ \\
\hline $\mathbf{1 1 - 1 4}$ godina & - & - & $50 \%$ & $35 \%$ \\
\hline $\mathbf{1 5 - 1 8}$ godina & - & $36 \%$ & $25 \%$ & $3 \%$ \\
\hline $\mathbf{2 1 9}$ godina & $100 \%$ & $64 \%$ & $10 \%$ & - \\
\hline UKUPNO & $100 \%$ & $100 \%$ & $100 \%$ & $100 \%$ \\
\hline
\end{tabular}

Izvor: anketni upitnik

Tablica prikazuje s koliko su godina pripadnici promatranih generacija dobili svoj prvi mobitel. Iz tablice se vidi kako su pripadnici Baby-boom generacije svoj prvi mobitel dobili tek oko punoljetnosti. Razlog tome može biti i činjenica kako ranije nije u toj mjeri bio prisutan mobitel u svakodnevnoj uporabi. Generacija X ima očekivani rezultat jer pojava mobitela i popularnost korištenja mobitela dolazi u srednjoškolskim danima. Generacija Y mobitel dobiva u višim razredima osnovne škole dok Generacija Z posjeduje svoj prvi mobitel već u nižim razredima osnovne škole pa i ranije.

Tablica 4 Koliko vremena dnevno provedeš na Internetu?

\begin{tabular}{|l|c|c|c|c|c|}
\hline & 1 do 2 sata & 3 do 5 sati & 6 do 8 sati & više od 8 sati & \\
\hline Baby-boom generacija & $83 \%$ & $17 \%$ & - & - & $100 \%$ \\
\hline Generacija X & $64 \%$ & $22 \%$ & $14 \%$ & - & $100 \%$ \\
\hline Generacija Y & $40 \%$ & $50 \%$ & $5 \%$ & $5 \%$ & $100 \%$ \\
\hline Generacija Z & $25 \%$ & $51 \%$ & $14 \%$ & $10 \%$ & $100 \%$ \\
\hline
\end{tabular}

Izvor: anketni upitnik

Pripadnici Baby-boom generacije najmanje vremena provode na Internetu. Razlog je činjenica kako su pripadnici navedene generacije već osobe u srednjim godinama te su radno aktivne ili slobodno vrijeme provode uz prijateljska druženja. Uz to pripadnici navedene generacije su osobe koje su aktivnosti i način korištenja mobitela učili u srednjim godinama te nisu vješti u istome te nisu skloni novim iskustvima. Generacija X ima nešto više zastupljeno vrijeme koje provode na Internetu jer su pripadnici ove generacije spretniji u korištenju mobitela te imaju interes za pretraživanjem Interneta. U jednoj mjeri su primorani koristiti mobitel zbog poslovnih zahtjeva. Pripadnici generacije $\mathrm{Y}$ i Z najviše vremena provode na Internetu što iz poslovnih razloga, što iz razonode. Pripadnicima navedenih generacija pretraživanje Interneta je svakodnevna pojava. 
Tablica 5 Što najčešće radiš kada si na Internetu? (moguće više odgovora)

\begin{tabular}{|l|c|c|c|c|}
\hline & $\begin{array}{c}\text { Baby-boom } \\
\text { generacija }\end{array}$ & Generacija X & Generacija Y & Generacija Z \\
\hline Čitam vijesti/novosti & $66 \%$ & $79 \%$ & $50 \%$ & $40 \%$ \\
\hline $\begin{array}{l}\text { Tražim informacije vezane za školu/ } \\
\text { fakultet/posao }\end{array}$ & $66 \%$ & $50 \%$ & $55 \%$ & $20 \%$ \\
\hline Koristim e-mail & $66 \%$ & $57 \%$ & $70 \%$ & $15 \%$ \\
\hline Dopisujem se s prijateljima & - & $36 \%$ & $45 \%$ & $17 \%$ \\
\hline Igram igrice & - & $14 \%$ & $20 \%$ & $53 \%$ \\
\hline $\begin{array}{l}\text { Pregledavam aplikacije Facebook, } \\
\text { Viber, WhatsApp, i dr. }\end{array}$ & $17 \%$ & $43 \%$ & $70 \%$ & $73 \%$ \\
\hline
\end{tabular}

Izvor: anketni upitnik

Pripadnici generacija Baby-boom, X i Y najčešće provode vrijeme na Internetu iz poslovnih razloga odnosno informiraju se o novostima te pretražuju potrebne informacije povezane s poslovanjem tvrtke te koriste e-mail. Pripadnici generacije Z najviše vremena provode na Internetu igrajući igrice ili pregledavajući aplikacije na mobitelu. Povežu li se dobivene informacije s tržištem, dolazi se do zaključka kako mladi poduzetnici svoje inovacije temelje upravo na igricama i aplikacijama. Unazad nekoliko godina, najveći broj inovacija bio je povezan s mobilnim aplikacijama (najbolji restorani, posjete muzejima, virtualna šetnja gradom, itd.) te uvijek popularne igrice koje su kreirali mladi poduzetnici. Često poduzetnici povezuju proizvod i uslugu (mobilnu aplikaciju) i time kreiraju jedinstven i inovativan proizvod na tržištu (npr. plišani medvjedić koji mjeri temperaturu djeteta i javlja na mobitel rezultat). Gledajući drugu perspektivu korištenja mobitela može se zaključiti kako pripadnici generacije Z ne koriste mobitel i Internet samo za kreiranje inovativnog tehnološkog proizvoda već koriste i za promociju vlastitog proizvoda. U velikoj mjeri pripadnici generacije $Y$ i Z svoje proizvode nude kupcima putem web shopa ili promoviraju i prodaju proizvode na popularnim društvenim mrežama. Razlog tome je što najviše vremena pripadnici većine generacija provode upravo na gore navedenim društvenim mrežama i na taj način prilaze ciljanoj populaciji. Uzmu li se u obzir dobiveni rezultati, može se reći kako je generacija $\mathrm{Z}$ u potpunosti generacija „urođenih digitalaca“ čime se potvrđuje prva postavljena hipoteza.

Nadalje, jedna od osnovnih karakteristika generacije Z, ali i popularno pitanje zadnjih nekoliko godina je pitanje okoliša. Mnogi autori smatraju kako je generacija Z ekološki osviještena jer živi u društvu u kojem se u velikoj mjeri postavlja pitanje onečišćenja i brige za okolišem. Stoga je potrebno razmotriti da li je generacija Z ekološki osvještenija od ostalih generacija. Daljnjim tekstom i grafovima potvrdit će se ili negirati zadana hipoteza. 


\section{Graf 3 Smatraš li da je recikliranje otpada važno?}

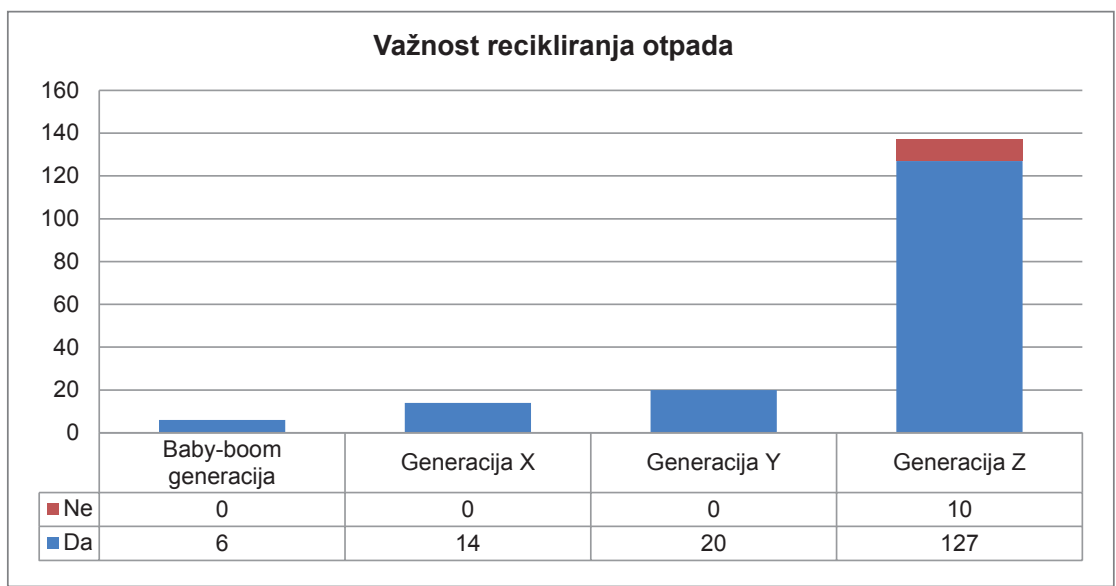

Izvor: anketni upitnik

Prema dobivenim rezultatima Baby-boom generacija te generacije X i Y u 100\%-tnom razmišljanju smatraju kako je recikliranje otpada važno. 93\% pripadnika generacije Z navode kako je važno reciklirati otpad. Kako bi se u potpunosti znalo je li potrebno potvrditi ili negirati zadanu hipotezu potrebno je grafički prikazati u kojoj mjeri pripadnici promatranih generacija razvrstavaju otpad jer često se zna dogoditi kako naša djela nisu u korelaciji s razmišljanjima.

\section{Graf 4 Razdvajaš li otpad?}

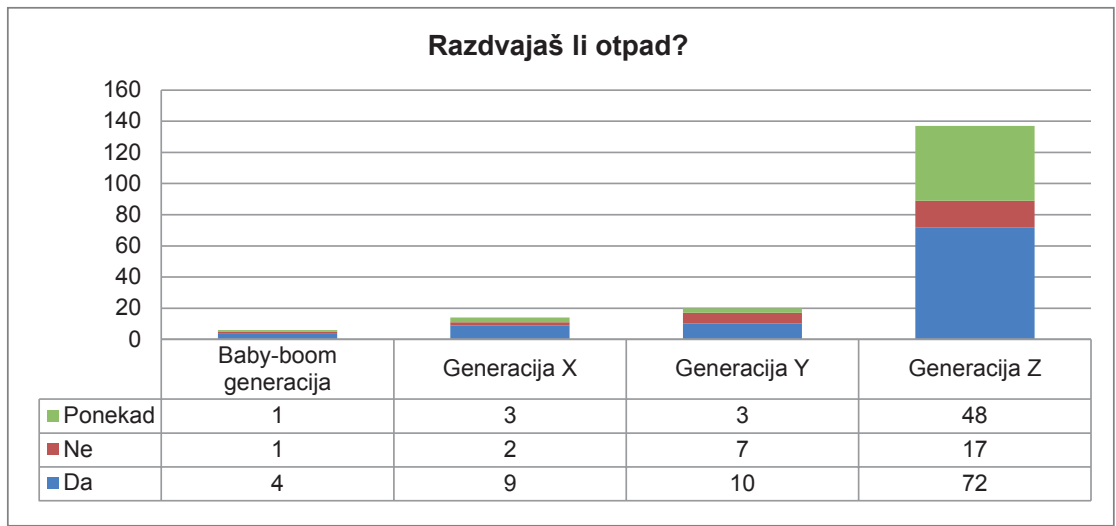

Izvor: anketni upitnik

Ako se pogledaju dobiveni rezultati, na prvu se može zaključiti kako u najvećoj mjeri otpad razdvajaju pripadnici Baby-boom generacije a najmanje pripadnici generacije Z. Ali, ako se detaljnije prouče dobiveni rezultati oni su u potpunosti drugačiji. Pribroje li se osobe koje razdvajaju otpad onima koje ponekad to čine, rezultati su sljedeći. 83\% pripadnika Baby- 
boom generacije reciklira otpad, $86 \%$ generacije $X$, dok samo $65 \%$ pripadnika generacije Y reciklira otpad. 86\% ispitanika generacije Z reciklira otpad. Što znači da u jednakoj mjeri pripadnici generacije $\mathrm{X}$ i generacije $\mathrm{Z}$ brinu o okolišu. Sve generacije navode kako su informacije o važnosti očuvanja okoliša dobili u školi ili putem medija.

Zaključno, druga zadana hipoteza, pripadnici generacije $Z$ osvješteniji su naspram drugih generacija, ne može se negirati, ali se ne može biti potvrditi. Uzmu li se u obzir dobiveni rezultati o važnosti očuvanja okoliša, javlja se pitanje o načinu zbrinjavanja otpada. Tu pripadnici generacije $Z$ mogu u velikoj mjeri kreirati svoje poslovne ideje vodeći se gore navedenim rezultatima i politikom kružne ekonomije ${ }^{1}$ koji mogu rezultirati poslovnim uspjehom.

U daljnjem tekstu i tablicom 7 stavit će se fokus na karakteristike generacije $\mathrm{Z}$, ali s osvrtom na poduzetništvo te će se preispitati posljednje dvije zadane hipoteze, tj. H3 - pripadnici generacije $\mathrm{Z}$ žele osnovati vlastito poduzeće i $\mathrm{H}_{4}$ - dualno obrazovanje ima za cilj ojačati poduzetništvo u Republici Hrvatskoj.

Tablica 7 Karakteristike Generacije Z s osvrtom na poduzetništvo

\begin{tabular}{|c|c|c|c|c|c|c|}
\hline & Xmin & Xmax & 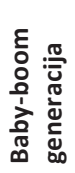 & 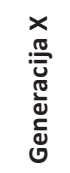 & 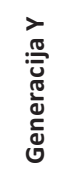 & 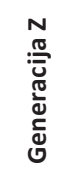 \\
\hline $\begin{array}{l}\text { Prilikom kupnje proizvoda izabirem poznatu marku } \\
\text { (brand) proizvoda. }\end{array}$ & 1 & 5 & 3,67 & 3,43 & 3,35 & 3,58 \\
\hline Bitan mi je dizajn (izgled) proizvoda. & 1 & 5 & 3,33 & 4,00 & 3,40 & 4,14 \\
\hline Nije mi bitna cijena i izgled već kvaliteta proizvoda. & 1 & 5 & 3,50 & 3,79 & 3,65 & 3,59 \\
\hline $\begin{array}{l}\text { Smatram kako bi u školi/na fakultetu trebalo biti više } \\
\text { predmeta povezanih s poduzetništvom. }\end{array}$ & 1 & 5 & 3,83 & 3,93 & 3,50 & 3,31 \\
\hline Volim riskirati u životu. & 1 & 5 & 2,33 & 2,64 & 3,40 & 3,55 \\
\hline Želim osnovati vlastito poduzeće. & 1 & 5 & 3,50 & 3,43 & 3,15 & 3.83 \\
\hline $\begin{array}{l}\text { Teorijsko znanje poduzetništva pomaže mi prilikom } \\
\text { shvaćanja procesa (aktivnosti) osnivanja vlastitog } \\
\text { poduzeća. }\end{array}$ & 1 & 5 & 3,67 & 3,71 & 3,30 & 3,49 \\
\hline $\begin{array}{l}\text { Smatram kako je bolje imati vlastito poduzeće a ne } \\
\text { raditi za druge. }\end{array}$ & 1 & 5 & 3,67 & 3,57 & 4,60 & 3,70 \\
\hline $\begin{array}{l}\text { Smatram kako je bitno ulagati u znanje i kvalitetne } \\
\text { materijale za rad. }\end{array}$ & 1 & 5 & 4,33 & 4,36 & 4,60 & 4,27 \\
\hline $\begin{array}{l}\text { Projektna nastava, terenska nastava, stručna } \\
\text { praksa i ostale aktivnosti u školi su me potaknule na } \\
\text { razmišljanje o osnivanju vlastitog poduzeća. }\end{array}$ & 1 & 5 & 3,17 & 3,00 & 3,60 & 3,39 \\
\hline $\begin{array}{l}\text { Projektna nastava, terenska nastava, stručna praksa i } \\
\text { ostale aktivnosti u školi pomogle su mi kod kreiranja } \\
\text { vlastite poduzetničke ideje (ideje o vlastitom poslu) }\end{array}$ & 1 & 5 & 3,17 & 3,07 & 3,80 & 3,33 \\
\hline $\begin{array}{l}\text { Facebook i ostale društvene mreže smatram } \\
\text { utjecajnim za pojedinca. }\end{array}$ & 1 & 5 & 3,67 & 3,36 & 3,85 & 3,43 \\
\hline
\end{tabular}




\section{Nastavak tablice 7}

\begin{tabular}{|c|c|c|c|c|c|c|}
\hline & $X \min$ & $X \max$ & 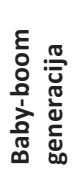 & 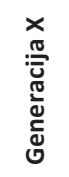 & 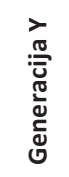 & 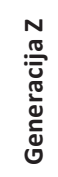 \\
\hline $\begin{array}{l}\text { Smatram kako je bolje osnovati posao s inovativnim } \\
\text { proizvodom. }\end{array}$ & 1 & 5 & 3,33 & 3,57 & 4,00 & 3,72 \\
\hline $\begin{array}{l}\text { Smatram kako je bolje osnovati posao s već } \\
\text { postojećim proizvodom na tržištu ali ga dodatno } \\
\text { modernizirati. }\end{array}$ & 1 & 5 & 3,67 & 3,36 & 3,55 & 3,88 \\
\hline $\begin{array}{l}\text { Svoje poslovanje bi usmjerio na inozemno tržište } \\
\text { (kupci i/ili poslovni partneri) }\end{array}$ & 1 & 5 & 3,50 & 3,86 & 3,75 & 3,77 \\
\hline
\end{tabular}

Izvor: anketni upitnik

Tablica 7 prikazuje sve ključne stavke za interpretaciju zadnjih dviju hipoteza. Uz to, prikazuje i karakteristike generacije Z s osvrtom na poduzetništvo i samo poimanje poduzetništva.

Ono što je karakteristično za generaciju $Z$ je to da pripadnici navedene generacije vole grafičke prikaze i teže vizualnom. Analizom dobivenih rezultata anketnim upitnikom potvrđena je navedena tvrdnja. Generacija Z uistinu voli slikovitost i ono što možemo očekivati od generacije $Z$ je da proizvode prati grafička obrada i veliki trud oko inovativnog dizajna proizvoda. Pripadnici generacije $Z$ također će velike napore ulagati u vizualni identitet tvrtke kao i izgled web stranice te stranice kreirane na popularnim društvenim mrežama kao jednim od najboljih načina prezentiranja proizvoda jer pripadnici generacije $Y$ i Z smatraju Facebook i ostale društvene mreže vrlo utjecajnim pa će samim time i svoje proizvode plasirati upravo tim putem. S druge strane, brand im nije bitan tako da će pripadnici generacije Z pokušati izaći na tržište kao samostalni proizvod.

Velika većina pripadnika generacije $Z$ želi osnovati vlastito poduzeće te smatra kako je bolje imati svoje poduzeće nego raditi za drugoga. To potvrđuje i sekundarno istraživanje koje je pokazalo pozitivan trend rasta poduzetnika u Republici Hrvatskoj. Drugim riječima, gospodarstvo će se temeljiti na većem broju manjih poduzeća ali će ponuda proizvoda biti jedinstvena uz veliki broj inovativnih proizvoda. Ovime se može potvrditi hipoteza $\mathrm{H}_{3}$ koja navodi da pripadnici generacije $Z$ žele osnovati vlastito poduzeće. U pravilu su to IT proizvodi različitih djelatnosti i industrija. Neki od popularnih inovativnih proizvoda koje navodi HAMAG-BICRO su proizvodi medicinske robotike, dronovi, električni automobili, eko ambalaža proizvoda, ekološka energetska opskrba marina, aplikacije za Internet transakcije, robotika i mnogi drugi inovativni proizvodi. Potvrda navedene hipoteze pronalazi se i u velikom broju sudionika i posjetitelja na organiziranom festivalu izuma, kreativnosti, snalažljivosti i poduzetništva Maker Faire Zagreb koji je ove godine održan u Tehničkom muzeju Nikola Tesla.

Pogledaju li se dobiveni rezultati koji povezuju dualno obrazovanje i poduzetništvo, oni su poražavajući. Sve promatrane generacije smatraju kako praktična nastava, terenska nastava, stručna praksa te mnoge druge aktivnosti koje se provode u školama u svrhu poticanja učenika na samostalnost i kreiranje vlastitog mišljenja i poticanja na stvaranje poduzetničkih ideja nisu dostatne za motivaciju osnivanja vlastitih tvrtki ili samo kreiranja 
inovativnog proizvoda. Zbog dobivenih rezultata ključne nadolazeće generacije Z, trebaju se preispitati krovne institucije rade li dovoljno na kvalitetnom provođenju Kurikuluma koji propisuje poduzetništvo kao jednu od ključnih kompetencija. Kada bi se u školama u većoj mjeri poticalo poduzetništvo i kritičko razmišljanje, a ne razmišljanje u „kutiji“, rezultati bi zasigurno bili drugačiji. Potrebno je učenicima dati veću slobodu i usmjeravati ih kod njihovih ideja, a ne sputavati u naumu. Zbog toga se zadnja postavljena hipoteza negira, ali svakako treba imati na umu kako na tržište rada dolazi nova generacija mladih ljudi, generacija Z, koja je svoje poduzetničke ideje kreirala bez obrazovnog sustava i spremna je uložiti napore i trud kako bi se probila na tržište. U ovom slučaju država treba financijskim sredstvima i ostalim pogodnostima olakšati rad mladih poduzetnika i dati im „vjetar u leđa“ jer jedino su oni ključ uspjeha, odnosno svojim inovacijama potaknut će gospodarstvo i samim time boljitak. Udruga inovatora Hrvatske te ostale neprofitne ili profitne institucije trebale bi biti više usmjerene prema mladima i ukazivati im na sve mogućnosti koje im se pružaju uključujući i savjetodavni rad.

\section{ZAKLJUČAK}

Poduzetništvo je staro koliko i ljudsko društvo, a pojmovi poduzetnik i poduzetništvo danas su sinonim gospodarskog razvoja. S obzirom na to da je poduzetništvo jedno od ključnih kompetencija svake osobe, potrebno je u svim sferama obrazovanja ulagati velike napore u poticanje kritičkog promišljanja svake osobe jer upravo iz njih proizlaze poduzetničke ideje. U Republici Hrvatskoj postoji pozitivan trend rasta poduzetnika i zbog toga bi država trebala ulagati veća financijska sredstva kako bi opstali na tržištu uslijed globalne konkurencije jer se hrvatsko gospodarstvo temelji na malim i srednjim poduzetnicima. Republika Hrvatska bi trebala biti usmjerena na prihvaćanje poduzetništva kao društvene, nacionalne, gospodarske i odgojno-obrazovne vrijednosti i sukladno tome prilagoditi sustav u cjelini. S obzirom na dobivene rezultate, generacija $\mathrm{Z}$ uistinu bi mogla biti nova generacija poduzetnika jer pripadnici te generacije posjeduju inovativne ideje i uz informatičku pismenost mogu kreirati proizvode i usluge jedinstvene na tržištu u tehnološkom smislu, ali mogu kreirati i proizvode koji će biti drugačiji od dosadašnjih po pitanju dizajna ili po načinu prezentiranja. Time bi se pripadnici drugih generacija trebali prilagoditi njima jer je generacija Z generacija budućnosti koja teži stvaranju nove moderne ekonomije 


\title{
A NEW GENERATION OF ENTREPRENEURS; GENERATION Z
}

\author{
Vedrana Simunic Rod, MSc \\ Private Grammar and Economics School Katarina Zrinski \\ Selska cesta 119, 10110 Zagreb, Croatia \\ Mobile: 098180 4066, e-mail: vedrana.simunic.rod@gmail.com
}

\begin{abstract}
The modern way of life, the introduction of technology in every aspect of ourlives, impatience, as well as the desire for independence and success, have created a new generation of entrepreneurs, the so-called $Z$ generation. A new generation of young people entering the job market with a new worldview is becoming more interesting to scientists, and their desire to come up with entrepreneurial ideas is attracting the interest of all generations. The $Z$ generation has become the main theme of this paper because of its characteristics, habits and the power to create trends. This paper aims to investigate whether this really is a new generation of entrepreneurs through the characteristics exhibited by its members, and how much technology influences the creation of their awareness, i.e. future business ideas. The primary and secondary research will explain in more detail the aim of the paper as well as the set hypotheses. The primary research will focus on the $Z$ generation, their habits, ideas, the adoption of technology as a modern way of life and how the youth exploits technology in pursuit of their goal. The secondary research will determine whether there is indeed an increase in the number of entrepreneurs in the Republic of Croatia and whether it is an indicator of the connection between technology and entrepreneurship. The final part of the paper will determine young people's level of interest in entrepreneurship and self-employment, and whether the early understanding of entrepreneurship has an impact on the realization of their entrepreneurial venture.
\end{abstract}

Keywords: Z generation; technology; entrepreneurship; self-employment 


\section{LITERATURA}

1. Bahtijarević-Šiber, F. i Sikavica, P. (2001). Leksikon menadžmenta. Zagreb: Masmedia.

2. Financijska agencija. Preuzeto s https://www.fina.hr/

3. Glass, A. (2007). Understanding generational differences for competitive success, Industrial and Comercial Training. Industrial and Commercial Training, 39(2): 98-103. doi: 10.1108 /00197850710732424

4. Gorupić, D. i Gorupić, D. jr. (1990). Poduzeće - Postanak i razvoj poduzetništva i poduzeća. Zagreb: Informator.

5. Gradečak, E. (2016). Istraživanje poduzetništva u Republici Hrvatskoj (Diplomski rad). Preuzeto s https://urn.nsk.hr/urn:nbn:hr:122:123657

6. Gregorić, M., Hegeduš, I. i Kolenko, K. (2018). Važnost inovacija i poduzetništva za ekonomski razvoj Republike Hrvatske. Obrazovanje za poduzetništvo - E4E: znanstveno stručni časopis o obrazovanju za poduzetništvo, 8 (posebno izd.), 23-43. Preuzeto s https://hrcak.srce.hr/196926

7. HAMAG-BICRO. Preuzeto s https://prvih25.hr/price/

8. Han, J. (2007, 13. studenog). Marketers Brace for Generation Z Customers. The Korea Times. Preuzeto s http://www.koreatimes.co.kr/www/news/nation/2007/11/123_13651.html

9. Hirsch, R. D., Peters, M. P. i Shepherd, D. A. (2005). Entrepreneurship. Boston: McGraw-Hill/ Irwin.

10. Hirsch, R. D., Peters, M. P. i Shepherd, D. A. (2016). Entrepreneurship (10 ${ }^{\text {th }}$ ed.). New York: McGraw Hill Education.

11. Hunjet, A. i Kozina, G. (2014). Osnove poduzetništva. Tehnički glasnik, 8. Varaždin: Sveučilište Sjever.

12. Kindrick Patterson, C. (2007). The Impact of Generational Diversity in the Workplace, The Diversity Factor, 15(3), 17-22.

13. Knežević, I. (2010). Upravljanje Generacijom Z (Diplomski rad). Ekonomski fakultet, Zagreb.

14. Kolaković, M. (2006). Poduzetništvo u ekonomiji znanja. Zagreb: Sinergija.

15. Levickaitè, R. (2010). Generations X, Y, Z: How Social Networks Form the Concept of the World Without Borders (The Case of Lithuania), LIMES, 3(2), 170-183.

16. McNamara, S. A. (2005). Incorporating generational diversity, AORN Journal, 81(6), 1149-1152.

17. Meister, J. C., Willyerd, K. (2010). 2020 Workplace, New York: Harper Business.

18. Montana, P. J., Petit, F. (2008). Motivating Generation $X$ and $Y$ on the Job and Preparing $Z$, Global Journal of Business Research, 2(2), 139-148.

19. Prensky, M. (2001). Digital Natives, Digital Immigrants, MCB University Press, 9(5), 1-6.

20. Reić, A. (2015, 12. studenog). Nova generacija mladih - generacija Z, Portal Europeo de la Juventud. Preuzeto s https://europa.eu/youth/hr/article/39/31499_es.

21. Rimac, M. (2012). Istraživanje obilježja Generacije Z - Radi li se zaista o novoj generaciji zaposlenika?, prema Notter, J. (2002.), Generational Diversity in the Workplace, Notter Consulting. Preuzeto s: http://www.notterconsulting.com/Articles/generationaldive.html

22. Škorić, A. (1995). Uvod u poduzetništvo. Zagreb: HITA-CONSULTING.

23. Vuković, I. (1999). Ekonomika poduzetništva u hotelijerstvu. Zagreb: Dalmatina.

24. Zemke, R., Raines, C. i Filipczak, B. (2000). Generations at Work: Managing the Clash of Veterans, Boomers, Xers and Nexterst in Your Workplace. New York: AMACOM.

25. Zimmerer, T. W. i Scarborough, N. M. (2005). Essentials of Entrepreneurship and Small Business Management. New Jersey: Prentice Hall. 